\title{
Islamic Bank Financing and Its Effects on Economic Growth: A Cross Province Analysis
}

\author{
Muhammad Anif Afandi ${ }^{1 *}$, Muhammad Amin ${ }^{2}$ \\ ${ }^{*}$ Corresponding author
}

\begin{abstract}
Islamic banking industry shows a reasonably good development, one of which is marked by an increase in service coverage in almost all provinces in Indonesia. However, the question is how far Islamic banking capable of contributing to the improvement of Indonesia's economic growth? The purpose of this research is to examine the role of Islamic banking in promoting inclusive economic growth with a sample of 33 provinces in Indonesia. The method used in this research is panel data regression using the fixed effects model. The results show that Islamic bank financing does not have an impact on Indonesia's economic growth. In other words, the results of the research provide information that the existence of Islamic banking in Indonesia has not yet give a significant impact on the welfare of Indonesian society.
\end{abstract}

Keywords: Islamic banking, economic growth, panel data

\begin{abstract}
Abstrak
Industri perbankan syariah menunjukkan perkembangan yang cukup baik yang salah satunya ditandai dengan peningkatan jangkauan layanan hampir di seluruh propinsi di Indonesia. Namun, yang menjadi pertanyaan adalah sejauh manakah perbankan syariah mampu memberikan kontribusi terhadap peningkatan pertumbuhan ekonomi Indonesia? Oleh karena itu, tujuan dari penelitian ini adalah untuk mengetahui bagaimana peran perbankan syariah melalui jenis pembiayaan yang disalurkan yaitu pembiayaan modal kerja, pembiayaan investasi, dan pembiayaan konsumtif dalam mendorong pertumbuhan ekonomi yang inklusif dengan sampel 33 propinsi di Indonesia. Metode yang digunakan dalam penelitian ini adalah regresi data panel dengan menggunakan fixed effects model. Hasil penelitian menunjukkan bahwa pembiayaan perbankan syariah tidak berpengaruh terhadap pertumbuhan ekonomi Indonesia. Dengan kata lain, hasil penelitian memberikan informasi bahwa keberadaan perbankan syariah di Indonesia belum memberikan dampak yang signifikan terhadap kesejabteraan masyarakat Indonesia.
\end{abstract}

Kata Kunci: perbankan syariah, pertumbuhan ekonomi, data panel

JEL Code: G21, O47

How to Cite:

Afandi, M. A., \& Amin, M. (2019). Islamic Bank Financing and Its Effect on Economic Growth: A Cross Province Analysis. Signifikan: Jurnal Ilmu Ekonomi, Vol. 8(2), 243-250. doi: http://dx.doi.org/10.15408/sjie.v8i2.10977 


\section{Introduction}

The Islamic banking industry is part of the financial sector and included as one of the contributors to Indonesia's national income calculation. After the issuance of Law No. 21 of 2008 , it is expected that the Indonesian banking industry will grow rapidly. So, the Islamic banking industry will have a positive impact on Indonesia's economic growth. The Islamic banking industry in Indonesia showed significant development. This development shows from the indicators, namely the number of institutions, number of offices, total assets, third party funds, and total financing, as shown in Table 1.

Table 1. The Development of Islamic Banking Main Indicators

\begin{tabular}{lccccc}
\hline Banking Industries & $\begin{array}{c}\text { Number of } \\
\text { Banks }\end{array}$ & $\begin{array}{c}\text { Number } \\
\text { of Offices }\end{array}$ & $\begin{array}{c}\text { Total Assets } \\
\text { (Billion Rupiah) }\end{array}$ & $\begin{array}{c}\text { Total Financing } \\
\text { (Billion Rupiah) }\end{array}$ & $\begin{array}{c}\text { Third Party Funds } \\
\text { (Billion Rupiah) }\end{array}$ \\
\hline $\begin{array}{l}\text { Islamic Commercial } \\
\text { Bank }\end{array}$ & 13 & 1,827 & 294.30 & 189.68 & 241.07 \\
Islamic Business Unit & 21 & 349 & 138.88 & 105.34 & 100.14 \\
Islamic Rural Bank & 168 & 459 & 11.24 & 8.52 & 7.17 \\
\hline \multicolumn{1}{c}{ Total } & 202 & 2,635 & 444.43 & 303.54 & 348.38 \\
\hline
\end{tabular}

Source: Financial Services Authority Republic of Indonesia (2018)

Table 1 explains that the leading indicators of Islamic banking which include the number of institutions, number of offices, total assets, third party funds, total financing and market share toward conventional banking industry have improved compared to the previous year. According to the Financial Service Authority (2018), the improvement in the leading indicators of Islamic banking was caused by the improvement in the primary financial performance of banks either of liquidity, efficiency, profitability or capital.

The research conducted by Abduh \& Omar (2012), and Rama (2013) concludes that there was a two-way relationship between Islamic bank financing and economic growth. This result means that Islamic bank financing can lead to an increase in economic growth, and economic growth can increase Islamic bank financing. Abduh \& Omar (2012) also show the positive relationship between Islamic bank financing and economic growth indicated that Islamic banking played an intermediary function effectively, which can bridge households that have a surplus of funds to households that have a deficit of funds.

The results of this research concluded that the positive relationship between Islamic banking and economic growth also conducted by Farahani \& Dastan (2013), Imam \& Kpodar (2016), and Zirek et al., (2016) who stated that the Islamic bank financing played its role in economic growth both in short and long-term. Imam \& Kpodar (2016) also concluded that Islamic banking considered more capable of increasing capital accumulation and having a better level of financial inclusion compared to conventional banking. The results of research 
conducted by Hayati (2014) that examined about the role of Islamic banking on Indonesia's economic growth concluded that the contribution of Islamic banking to Indonesia's economic growth showed a relatively small contribution.

The different result shows by Hachicha \& Amar (2015) that concludes that Islamic bank financing did not show a positive impact on economic growth in Malaysia in the longterm. The positive impact of Islamic bank financing on economic growth only occurred in the short-term due to Islamic banking activities, which tended to orients in carrying out short-term financing. Meanwhile, the total assets of Islamic banking did not have a positive effect on Indonesia's economic growth. Islamic banking has the potential to foster inclusive economic growth (Fasih, 2012).

Based on the previous research, further research needs regarding the effects of Islamic bank financing on Indonesia's economic growth. This research is intended to bridge the gap that occurred in previous research that showed two different tendencies. In this research, it will only focus on the effects of Islamic bank financing on Indonesia's economic growth with data from 33 provinces in Indonesia. This research is to show and analyze the contribution of Islamic bank financing on inclusive Indonesia's economic growth.

\section{Method}

This research conducted by using secondary data with the type of panel data from 33 provinces in Indonesia during the period 2013 - 2017. The data obtained from the publication of the Central Bureau of Statistics (BPS) and Islamic Banking Statistics of the Financial Services Authority (FSA) Republic of Indonesia. The equation that uses in this research as follow:

$$
Y_{i t}=\alpha+\beta_{1} X_{1 i t}+\beta_{2} X_{2 i t}+\beta_{3} X_{3 i t}
$$

Where: $\mathrm{Y}$ is economic growth; $\mathrm{X}_{1}$ is working capital financing; $\mathrm{X}_{2}$ is investment financing; $\mathrm{X}_{3}$ is consumer financing.

Three models that use in panel data estimation are common effect model (CEM), fixed effect model (FEM), and random effect model (REM). In order to determine the best model between CEM, FEM, and REM, this research is using Chow and Hausman test. According to Baltagi (2006), the Chow test was used to choose the best model between CEM and FEM. Furthermore, according to Baltagi (2006) to choose the best model between FEM and REM, this research is using Hausman-test.

\section{Result and Discussion}

Islamic banking should be an excellent opportunity to be a contributor to economic growth in Indonesia. As a country with a majority Muslim population, of course, this is very reasonable to express. To find out how the role of Islamic bank financing on Indonesia's economic growth then conducted tests with several stages in Table 2. 
Table 2. The Output of Chow and Hausman Test

\begin{tabular}{cccc}
\hline & The Output of Chow Test & & \\
\hline Effects Test & Statistic & d.f. & Prob. \\
\hline Cross-section F & 399.644598 & $(29,117)$ & 0.0000 \\
Cross-section Chi-square & 690.861315 & 29 & 0.0000 \\
\hline Test Summary & The Output of Hausman Test & & \\
\hline Cross-section random & Chi-Sq. Statistic & Chi-Sq. d.f. & Prob. \\
\hline
\end{tabular}

Source: Data processing

Chow test output, which is done to select the best model between CEM and FEM, the result show that the p-value is significant. The result shows that the best model is the FEM. After selecting the model between CEM and FEM using the Chow test, the Hausmann test is then conducted to choose the best model between FEM and REM. Based on Hausmann test output, it knows that the p-value is significant; it means that the best model is FEM. Based on Table 3, it knows that all the correlation coefficient values between the independent variables used are in the number $<0.8$. It can conclude that the panel data regression estimation that is using in this model is free from multicollinearity.

Table 3. The Output of Multicollinearity Test

\begin{tabular}{llll}
\hline & LOGWORCAP & LOGINV & LOGCONS \\
\hline LOGWORCAP & 1.000000 & 0.571251 & 0.020501 \\
LOGINV & 0.571251 & 1.000000 & -0.210673 \\
LOGCONS & 0.020501 & -0.210673 & 1.000000 \\
\hline
\end{tabular}

Source: Computed by Authors (2019)

Furthermore, Table 4 shows the output of heteroscedasticity using Glejser test. This test shows whether there is an inequality of variance from the residual in one observation to another observation. From the result of Glejser test shows that the model is free from heteroscedasticity.

Table 4. The Output of Glejser Test

\begin{tabular}{cccc}
\hline Variable & Coefficient & t-Statistic & Prob. \\
\hline LOGWORCAP & 0.000692 & 0.249665 & 0.8033 \\
LOGINV & 0.004858 & 1.043106 & 0.2990 \\
LOGCONS & 0.002159 & 0.716807 & 0.4749 \\
C & 0.031119 & 1.088139 & 0.2788 \\
\hline
\end{tabular}

Source: Data processing

After testing CEM, FEM, and REM and selecting the best model using Chow test and Hausmann test, it found that FEM model was the best model to know and analyze the effects of Islamic bank financing on Indonesia's economic growth. The FEM model also fulfills the criteria 
of BLUE after tested of the classical assumptions, namely multicollinearity and heteroscedasticity. From the FEM model produced, then the model equation can be written as follows:

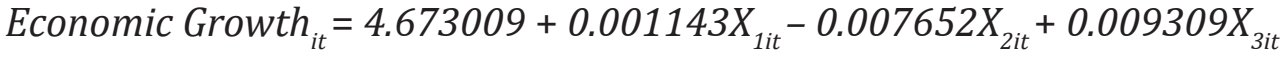

From the result in Table 5 shows Islamic banking financing, either for working capital, investment, and consumption do not have an impact on Indonesia's economic growth. The value of $\beta 0$ as big as 4.673009 it means that the average value of economic growth if working capital financing, investment financing, and consumer financing channeled by Islamic banking to MSMEs are relatively low. In the F-test shows the probability value about 0.000000 . It means that simultaneously, the independent variables used namely working capital financing, investment financing, and consumer financing have a significant effect on the economic growth.

Table 5. Regression Output Using CEM, FEM and REM Methods

\begin{tabular}{cccc}
\hline Variable & CEM & FEM & REM \\
\hline LOGWORCAP & $-0.061558^{*}$ & 0.001143 & 0.000650 \\
& $(-1.701695)$ & $(0.198283)$ & $(0.113088)$ \\
LOGINV & 0.054353 & -0.007652 & -0.006501 \\
& $(1.147408)$ & $(-0.790296)$ & $(-0.674858)$ \\
LOGCONS & $-0.193005^{* * *}$ & 0.009309 & 0.006774 \\
& $(-7.024059)$ & $(1.1486652)$ & $(1.086704)$ \\
C & $5.326264^{* * *}$ & $4.673009^{* * *}$ & $4.678116^{* * *}$ \\
& $(21.78254)$ & $(78.59270)$ & $(30.24620)$ \\
\hline
\end{tabular}

Source: Data processing

This research is different from previous studies. El-Galfy \& Khiyar (2012), Kalim et al., (2016), and Boukhatem \& Moussa (2018) shows that there is a positive impact between Islamic bank financing on economic growth. The previous studies show that Islamic bank financing can stimulate economic growth if supported by clear regulations in a country. Meanwhile, investment-financing variable shows the different result with two previous independent variables (working capital financing and consumer financing) that are not significantly influencing on economic growth. Hachicha \& Amar (2015) state that there is a negative relationship between investment financing and economic growth. The study stated that in the long-term economic growth in Malaysia did not influence Islamic bank financing due to the orientation of Islamic banking, which tend to conduct short-term financing using Murabaha contracts. Malaysian Islamic banking tends to reduce the use of mudharabah contracts as the main instrument in profit and loss sharing activities.

Another explanation about the real situation regarding Islamic bank financing and its effects on economic growth can explain through the Islamic Finance Progress Report issued by the Financial Service Authority. The report stated that there was a decreasing in the financing portion of the productive sector due to higher growth in consumer financing as big as 18.56 percent (YoY) or IDR19.19 trillion compared to the growth of productive sector financing as big as 12.95 percent or IDR 19.59 trillion. Besides, the report also explained that from the total productive financing channeled by Islamic banking as big as 58.22 percent in 2017 that consists by 35.02 percent of working capital financing and the remaining as big as 23.20 percent was 
investment financing. The data show that there is a declining if compared to 2016, which was 35.38 percent and 24.02 percent, respectively. Meanwhile, the portion of consumer financing had increased in 2017 from 40.60 percent in 2016 to 41.78 percent in 2017.

Figure 1. Development of Islamic Bank Financing based on Types of Use

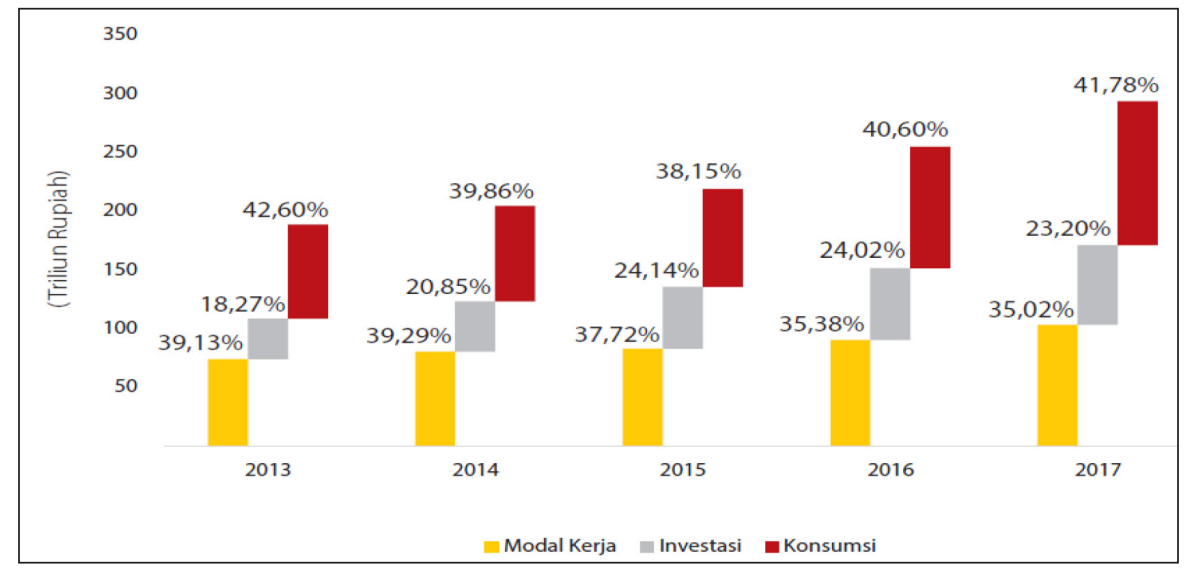

Source: Financial Service Authority (2018)

Figure 1 provides information that the portion of investment financing is the smallest financing portion channeled by Islamic banking when compared to working capital financing and consumer financing. This condition is one of the real reasons why the relationship between investment financing and economic growth is not significant due to the relatively small portion of investment financing distribution.

Figure 2. The Development of Islamic Bank Financing based on the Contracts Used

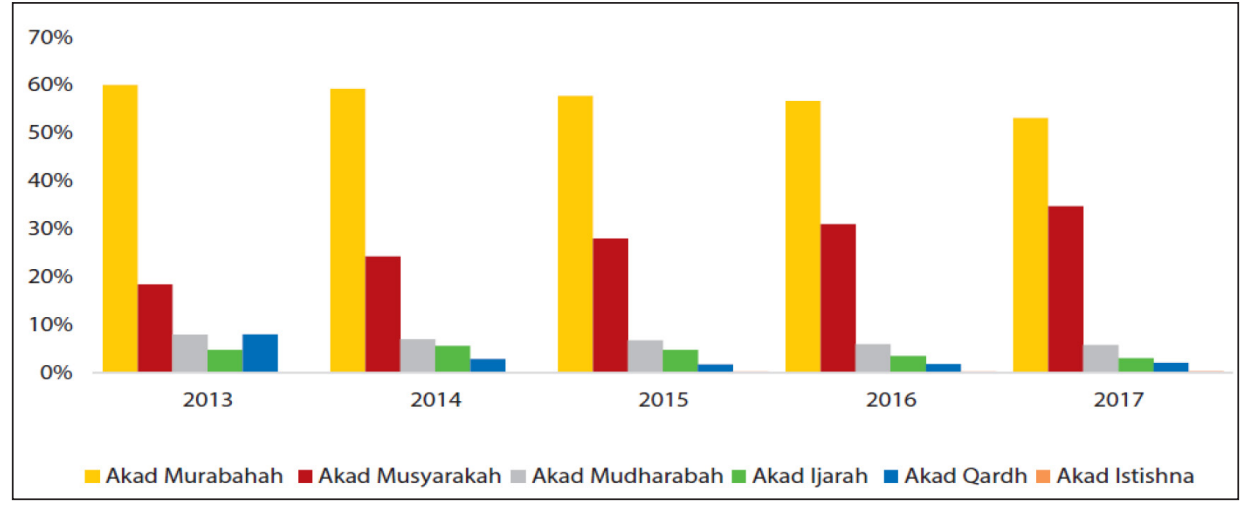

Source: Financial Service Authority (2018)

Those conditions also prove by Hachicha \& Amar (2015) that Islamic banking still oriented toward financing that was short-term or tended to channel their financing that was consumptive rather than productive. This fact was evident in the financial service authority report that explained the Murabaha contracts still dominate financing activities channeled by Islamic banking, which was more than 50 percent of the total financing channeled (See Figure 2). Besides the declining in the portion of productive financing and Islamic banking 
are still oriented with consumer financing by using Murabaha contracts. Other problems that can explain why there is no impact between Islamic bank financing and Indonesia's economic growth locating from the business category provided by Islamic bank financing. Although, Léon and Weill (2018) state the Islamic banking development exerts a positive impact on access to credit when conventional banking development is low.

From Figure 3, it can explain that Islamic banking is still oriented to channel the financing to customers with non-MSMEs categories rather than MSMEs. From 2014 - 2017 as outlined in Figure 3, it can explain that the trend of financing distribution to customers with non-MSMEs categories tended to increase and conversely the trend of financing distribution to customers with MSMEs categories tended to decrease. This phenomenon can answer why working capital financing and investment financing have no significant effect on economic growth due to the distribution of funding to MSMEs tended to be still low. Although according to Abedifar et al., (2016), Islamic banks can affect the financial deepening and intermediation positively. The government should consider implementing proactive and improve the economic, infrastructure and institutional policies to accelerate the Islamic finance growth (Sarwer et al., 2013; Kassim, 2016; Yüksel \& Canöz, 2017; Boukhatem and Moussa, 2018).

\section{Figure 3. The Development of Productive Sector Financing in MSMEs and Non-MSMEs Business Categories}

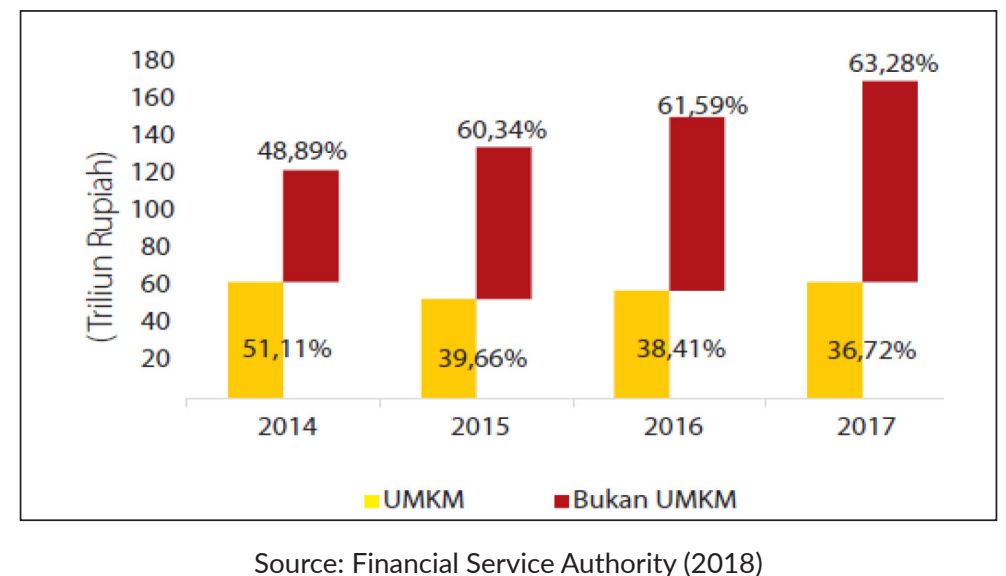

\section{Conclusion}

This research tries to find out how the effects of financing channeled by Islamic banking to Micro Small and Medium Enterprises (MSMEs) (working capital and investment financing) and non-MSMEs (consumer financing) to economic growth by using panel data from 33 provinces in Indonesia. The results showed that all independent variables, namely working capital financing, investment financing, and consumer financing, did not significantly influence on Indonesia's economic growth. However, working capital financing and consumer financing show a positive influence on economic growth. Meanwhile, investment financing shows a negative influence on economic growth. The results of this research can explain to the results of previous research stating that the contributions of Islamic banking still provide a small contribution to economic growth. 


\section{References}

Abduh, M., \& Omar, M. A. (2012). Islamic Banking and Economic Growth: the Indonesian Experience. International Journal of Islamic and Middle Eastern Finance and Management, 5(1), 35-47. https://doi.org/10.1108/17538391211216811.

Abedifar, P., Hasan, I., \& Tarazi, A. (2016). Finance-Growth Nexus and Dual-banking Systems: Relative Importance of Islamic Banks. Journal of Economic Behavior and Organization, 132(supplement), 198-215. https://doi.org/10.1016/j.jebo.2016.03. 005.

Baltagi, B. H. (2006). Panel Data Econometrics: Theoretical Contributions and Empirical Applications. Amsterdam: Elsevier.

Boukhatem, J., \& Moussa, F. B. (2018). The Effect of Islamic Banks on GDP Growth: Some Evidence from Selected MENA Countries. Borsa Istanbul Review, 18(3), 231-247. https://doi.org/10.1016/j.bir.2017.11.004

El-Galfy, A., \& Khiyar, K. A. (2012). Islamic Banking and Economic Growth: A review. Journal of Applied Business Research, 28(5), 943-956. https:/doi.org/ 10.19030/jabr.v28i5.7236

Farahani, Y. G., \& Dastan, M. (2013). Analysis of Islamic Banks' Financing and Economic Growth: a Panel Cointegration Approach. International Journal of Islamic and Middle Eastern Finance and Management, 6(2), 156-172. https://doi.org/10.1108/ 17538391311329842

Fasih, F. (2012). Inclusive Growth in India Through Islamic Banking. Procedia Social and Behavioral Sciences, 37, 97-110. https://doi.org/10.1016/j.sbspro.2012.03.278.

Gujarati, D. N., \& Porter, D. C. (2017). Basic Econometrics. USA: The McGraw-Hill.

Hachicha, N., \& Amar, A. B. (2015). Does Islamic Bank Financing Contribute to Economic Growth? The Malaysian Case. International Journal of Islamic and Middle Eastern Finance and Management, 8(3), 349-368. https://doi.org/10.1108/IMEFM-07-2014-0063

Hayati, S. R. (2014). Peran Perbankan Syariah terhadap Pertumbuhan Ekonomi Indonesia (The Role of Islamic Banking on The Indonesian Economic Growth). Indo-Islamika, 4(1), 41-66.

Imam, P., \& Kpodar, K. (2016). Islamic banking: Good for growth? Economic Modelling, 59, 387-401. https://doi.org/10.1016/j.econmod.2016.08.004.

Kalim, R., Mushtaq, A., \& Arshed, N. (2016). Islamic Banking and Economic Growth: A Case of Pakistan. Islamic Banking and Finance Review, 03(July), 29-43. https://doi. org/10.32350/ibfr.2016.03.03

Kassim, S. (2016). Islamic Finance and Economic Growth: The Malaysian Experience. Global Finance Journal, 30, 66-76. https://doi.org/10.1016/j.gf.2015.11.007.

Léon, F., \& Weill, L. (2018). Islamic Banking Development and Access to Credit. PacificBasin Finance Journal, 52, 54-69. https://doi.org/10.1016/j.pacfin.2017.04.010.

Rama, A. (2013). Perbankan Syariah dan Pertumbuhan Ekonomi Indonesia (Islamic Banks and the Indonesian Economic Growth). Signifikan: Jurnal Ilmu Ekonomi, 2(1), 33-56. https://doi.org/10.15408/sjie.v2i1.2372

Sarwer, M. S., Ramzan, M., \& Ahmad, W. (2013). Does Islamic Banking System Contributes to Economy Development. Global Journal of Management and Business Research, 13(2), 60-68.

Yüksel, S., \& Canöz, I. (2017). Does Islamic Banking Contribute to Economic Growth and Industrial Development in Turkey? Ikonomika, 2(1), 93-102.

Zirek, D., Boz, F. C., \& Hassan, M. K. (2016). The Islamic Banking and Economic Growth Nexus: A Panel VAR Analysis for Organization of Islamic Cooperation (OIC) Countries. Journal of Economic Cooperation and Development, 37(1), 69-100. 